\title{
Fish news: perceptual skills, technique and distributed cognition in mullet fishing
}

\author{
Rafael Victorino Devos' \\ Gabriel Coutinho Barbosa' \\ Viviane Vedana'
}

'Universidade Federal de Santa Catarina, Florianópolis/SC, Brasil

\begin{abstract}
This paper presents an investigation about perception of the environment, technique and distributed cognition, with fishermen and schools of mullets, on beaches in southern Brazil. We discuss the relationship of audiovisual research techniques with the techniques of the body and operational sequences involved in the lookout for schools of mullets, paddling of non-motorized canoes and net casting, revealing knowledge embedded in these practices. The examination of the exchange of pictures and videos of fish among fishermen on their smartphones reveals a distributed cognition system that includes radio communication and other traditional ways of obtaining and confirming "fish news". This is a collective form of monitoring the ways that fish appear on the coast. The objective of the study is to understand the use of "new technologies" without disassociating them from the technicity of collective practices and knowledge systems of artisanal fishing.
\end{abstract}

Keywords: perception of the environment; distributed cognition; technique; artisanal fishing. 


\section{Notícias de peixes:}

\section{habilidades perceptuais, técnica e cognição distribuída na pesca da tainha}

\section{Resumo}

Apresenta-se uma investigação sobre percepção, técnica, e cognição distribuída envolvendo coletivos de pescadores e peixes durante temporadas de pesca da tainha, no litoral de Santa Catarina, sul do Brasil. Discute-se o engajamento das técnicas de pesquisa, envolvendo a produção de imagens e sons, com as técnicas corporais e cadeias operatórias das práticas de vigia de cardumes, navegação de canoas não motorizadas e arrasto de rede no cerco dos peixes, para revelação dos conhecimentos implicados nesta modalidade de pesca. Aborda-se as trocas, entre os pescadores, de imagens feitas com smartphones da presença dos cardumes no mar, revelando um sistema de cognição distribuída envolvendo comunicação por rádio e outras formas tradicionais de obter e confirmar "notícias de peixe", um monitoramento coletivo dos modos dos cardumes "se mostrarem" na paisagem costeira. Propõe-se entender o uso de "novas tecnologias" sem dissociá-las da tecnicidade de práticas coletivas e sistemas de conhecimento da pesca artesanal.

Palavras-chave: percepção do ambiente; cognição distribuída; técnica; pesca artesanal. 


\title{
Fish news: perceptual skills, technique and distributed cognition in mullet fishing?
}

\author{
Rafael Victorino Devos \\ Gabriel Coutinho Barbosa \\ Viviane Vedana
}

The mullet catch in 2016 was the best in the past 40 years for artisanal fishing on the Santa Catarina state coast. The three thousand tons of gray mullet caught ${ }^{2}$ by artisanal fishermen contradict theses that both artisanal fishing and schools of fish are disappearing from the beaches of Southern Brazil, substituted by industrial deepsea fishing, modernization of tradition or tourism. The success of artisanal fishing is the result of the effort of fishing collectives that work along the beaches and the conquest of specific policies for the sector, such as the liberation of the fishing season for this modality before others ${ }^{3}$ as well as heritage policies. The effectiveness of the small boats to "matar peixe" [kill fish] sparked greater attention from environmental protection agencies to the potential of artisanal fishing. While fishing with small motorized boats, which is known as "caça de malha" [literally "net hunting"], depends on the issue of licenses, special zoning along the coast and control of the equipment used (the size of the boat, the types of nets, the mesh size, etc.), the use of beach seine nets, has been given special consideration as "traditional", or even "cultural fishing". Nevertheless, although heritage policies often characterize the use of beach seines in the so-called "rhetoric of loss" (Gonçalves, 1996), as a practice that is condemned to disappear and remain celebrated in museums and eulogies, the effectiveness of this modality has been surprising in recent mullet fishing seasons in Santa Catarina.

Even if its artisanal character is also considered in terms of continuity of the forms of the social division of labor and use of traditional equipment, such as dugout paddle canoes, in this study we propose another approach, expanding the notion of technical effectiveness that is involved. We reflect on the artisanal component of mullet fishing with beach seine nets through studies of perceptual skills in the environment and of the chaines opératories [operational sequences] involved in the techniques used by the parelha [crew], as the collective of fishermen and their fishing equipment is known in the region. To do so, we consider these operational sequences through audiovisual description of the sequences of gestures that are important to the encounter between fishermen and schools of fish on the beaches of Florianópolis, Santa Catarina Island. ${ }^{4}$

\footnotetext{
A preliminary version of this study was presented at the 30a Brazilian Anthropology Meeting, held from 3-6 August, 2016, João Pessoa in the working group "Anthropology of Technique" and partially at the Round Table "Visual Anthropology and Hypermedia". In previous versions, the images and part of these arguments were debated at the Visual Anthropology International Meeting (EIAV USP), November 2014, São Paulo, and at the I Environment, Perception and Practice Seminar, October 2014, Florianópolis. We would like to thank our colleagues who debated the issue with us at various times, in particular: Brisa Catão Totti, Fabio Mura, Stelio Marras, Jeremy Jean Paul Loup Deturche, Carlos Sautchuk, Thiago Motta Cardoso, Julio César Stabelini, Marcos Alexandre Albuquerque, Fernanda Rechenberg, Sylvia Caiuby Novaes, Rose Satiko Hikiji e Paula Morgado.

2 Data from an article in G1 SC, de 29/06/2016: http://g1.globo.com/sc/santa-catarina/noticia/2016/o6/dia-do-pescador-em-sc-e-marcado-pelo-ultimosdias-de-safra-da-tainha.html last accessed on 20/07/2016.

3 Since 2015, mullet fishing on the Santa Catarina coast has adopted a differentiated calendar for permission to fish. While artisanal fishing with beach seine nets is permitted from May 1 to July 31, artisanal fishing on boats can only begin on May 15 and industrial fishing is permitted from June 1 to July 31.

4 Similar forms of social organization of fishing collectives as we describe in this text are presented in important ethnographies in studies of fishing in Brazil (Kant de Lima and Pereira, 1997; Mussolini, 1945; Diegues, 1983) in which are present the vigias lookouts (olheiros, espias) [watchers, spies], owners, nets and paddle canoes in the so-called pequena pesca [small fishing]. But unlike these studies, which usually emphasize the traditional component of this practice and its modernization or disappearance amid conflicts over use of the coast, in Santa Catarina an important revival of artisanal fishing has been perceived in recent years, and particularly of beach seine fishing, in the daily life of these fishing communities and in the public policies that articulate environment, heritage and fishing.
} 
Since we began the study5 in 2014, we visited some of the beaches of Florianópolis, recording in audio and video and photographing fishermen in their daily activities. They constantly challenged us to capture with the camera what they were really interested in: fish on the beach. This challenge resulted in the documentary "Ver Peixe" [seeing Fish] (2017), which we produced by accompanying the work of a fishing crew, on a beach in the city of Florianópolis, Barra da Lagoa, for 4 seasons. In this sense, this article also reflects the construction of an audiovisual anthropology whose technique is considered in correspondence with the fishing techniques: images and sounds that are the materialization of this encounter of the collectives of fishermen with the collectives of fish, together with the atmospheric and oceanic elements of the fishing season. In place of metaphoric representation, we proposed the challenge of an ecological realism. To be able to record the encounter of fishermen with fish implied inscribing in the images the effects of these efforts that come together on the beach, in an effort to synchronize the rhythm of the audiovisual narrative with the rhythmic interlinking of the fishing crew with the schools of fish. It also involved, as we discuss here, inserting the narratives themselves in a sequence of technical operations that encompass an ecology of practices and instruments of broad perception of the movement of schools of fish on the Southern coast of Brazil.

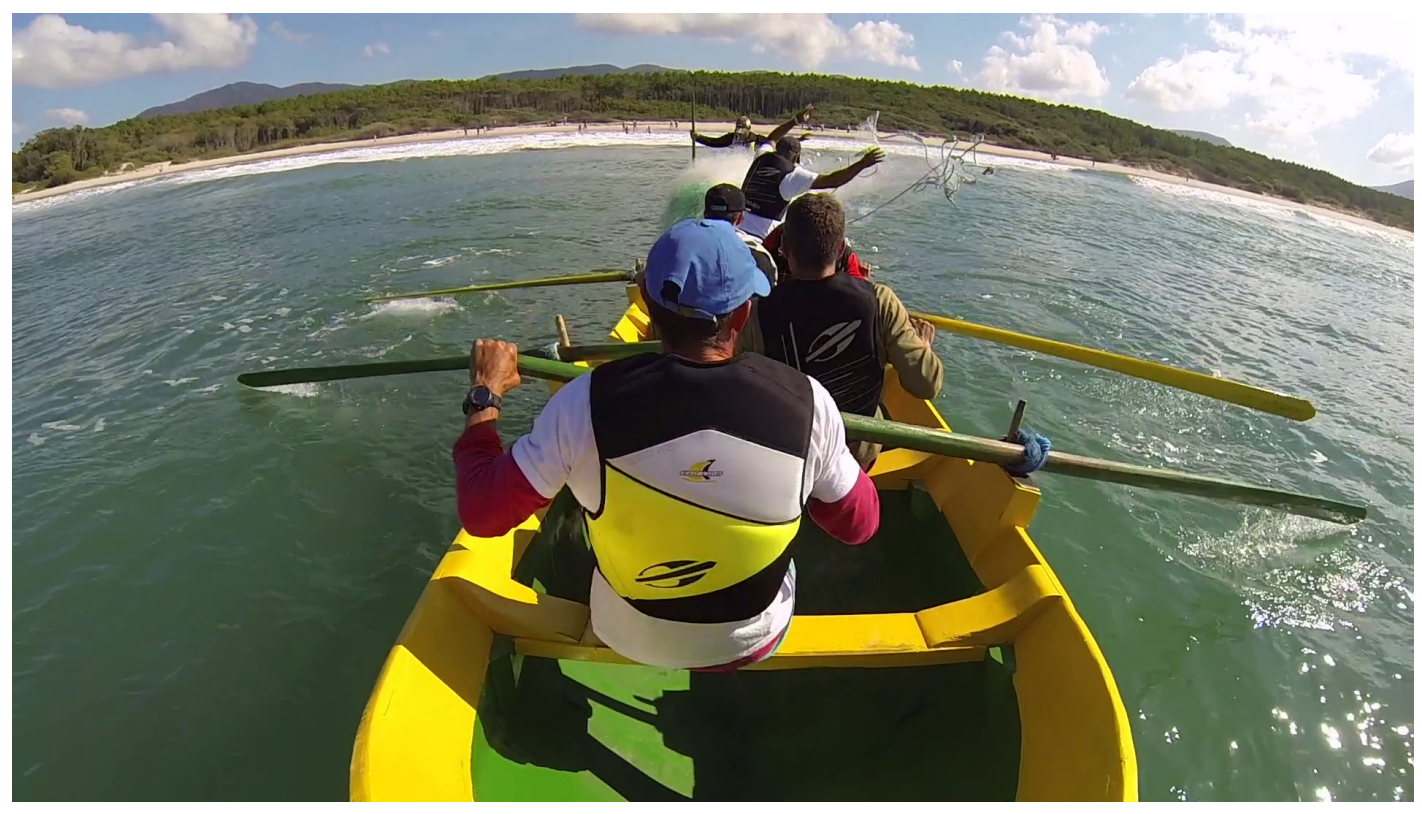

Image 1: image from the trailer for the film Ver Peixe (2017) available on the research site http://verpeixe.tumblr.com/post/169733068948/verpeixe-seeing-fish-2017-46-min. Last accessed on 10/07/2018.

\section{Beach seine fishing crews: artisanal as a political category}

On the Southern coast of Brazil, particularly in Santa Catarina, in the months from May to July, the mullet fishing season is intensely lived. This is a seasonal phenomenon that inserts new rhythms in the coastal landscape, with the arrival of cold winds, currents of icy waters, and schools of thousands of mullets that are followed by dolphins, penguins, whales, sea lions, seagulls and vultures, which are all found along with collectives of fishermen, nets and boats. The mullet are the standouts, appearing on the beaches, in the waves, in fish stores, restaurants, on the internet, in videos and in photos that circulate on cellphone apps, on TV reports and in newspapers.

\footnotetext{
5 This article is the result of studies conducted within the project "Lugares Acontecem: mapeamento em hipermídia de itinerários, práticas cotidianas e percepções ambientais na pro- dução da paisagem urbana", financed by CNPQ - Edital MCTI/CNPQ/Universal 14/2014. We would like to thank CNPq for the support in realization of the work.
} 
Fishing takes over the spaces that had been occupied by bathers, surfers and tourists in the hot months. The weather forecasts focus on the winds that bring cold and rain, instead of sun and warmth. The daily reports on wave conditions make way for reports on fishing. This is what the fishermen want to know: on what beach will the schools of mullet "show themselves", in which direction are they heading, where may they appear next, where will it "dar peixe" [give fish], today.

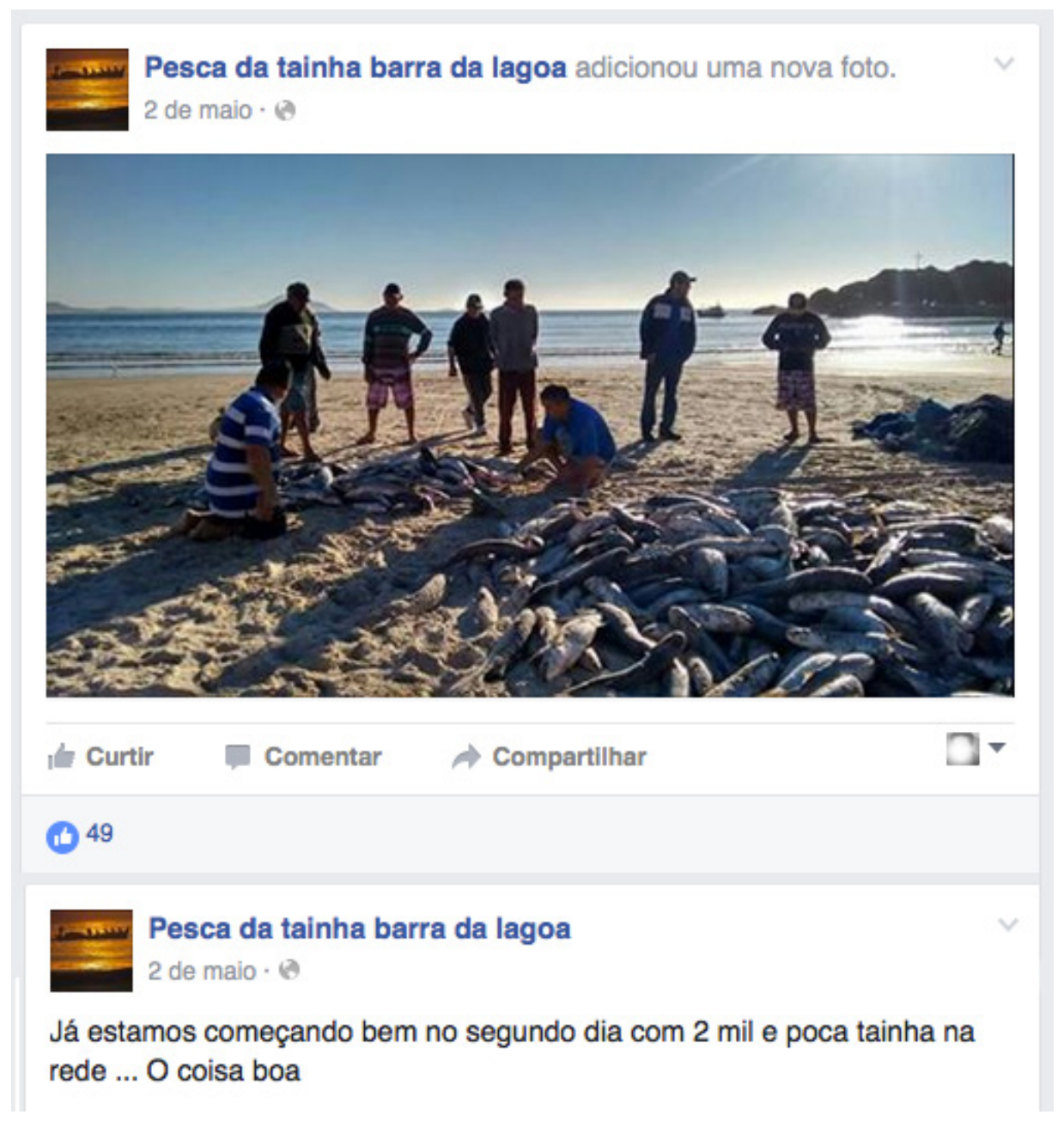

Image 2: post by fishermen from Barra da Lagoa during the 2016 season. "We started the season well with two thousand of mullet. Great". Source: http://www.facebook.com. Last accessed 20/06/2016.

Organized collectively, in the past decade the fishermen in these artisanal fishing modalities have conquered regulations to insure better working conditions from public agencies associated to uses of the coast, in the form of laws or norms that govern fishing practices and the use of the beach during the fishing season. Each year the artisanal fishermen must renegotiate access to the right to begin their work one month before the industrial fishing boats, as well as the exclusive right to use the beach for fishing, prohibiting uses such as surfing, and other nautical sports. They also use laws related to cultural heritage to gain permission for the temporary installation of fishing shacks and lookout posts in the sand dunes, rocky coasts and other areas in the city where environmental preservation laws do not permit construction.

The fishermen who work in beach seine fishing in Santa Catarina have diverse backgrounds ranging from experienced professionals in the sector, who also fish in other months of the year, to retirees, young beginners, informal and formal workers in restaurants, public or private sector employees and others who take their 
vacations during the mullet season to fish. Although tradition, heritage and culture are categories used to refer to the continuity of this practice in relation to the social memory of their communities and families, it is the artisanal category that is now politically waged, as their distinction.

The artisanal component is raised as a condition (with an environmental component), a mode of action and an objective of this practice. The fish need to come to the beach, and for this reason, the beach should be prepared to attract fish by avoiding the intense activity found in the summer. On the other hand, it is necessary to be prepared to make the catch, by performing a series of actions that constitute the lanço, [the Portuguese word used for the launching of the canoe and the casting of the net]. The success of the launch simultaneously confirms its condition and effectiveness through the presence of mullet on the beach.

The capture of the mullet from the beach depends on the perceptive ability of the fishing crew to see the fish, that is, to anticipate their passage through the space of capture with the net at the edge of the beach. The presence of fish in the sea occurs between changes in wind direction and ocean currents, combined with the movement of other elements on the landscape in a complexity that we will soon see in greater detail. The movement of the crew, its passage from a state of waiting to the intense moment of circling and capturing the fish, depends on its ability to sense the movement, which is also inconstant, of the schools of mullet in the sea.

Marcel Mauss redefined techniques of the body as an anthropological question: modes of acting that are traditional, because they are socially learned, and effective that have the body as the primary object and technical medium (Mauss, 2003: 407). In the case of artisanal fishing, technical effectiveness does not immediately signify economic efficiency, as an optimization of means. This technical effectiveness involves reaching the objectives of the practice in question, as we see, "killing fish", capturing schools of large mullet, overcoming their escape tactics, dragging them to the beach, inserting them in exchanges and socialities of the local collectives, articulating predation, abundance, gift and reciprocity. The continuity of these shared collective modes of conducting the practice determines the traditional component of the fishing. The effectiveness of this fishing depends on a synchronized chain of gestures of the fishing crew that are used to find the fish from distinct places. It also involves a knowledge of the environment, which is experienced with the entire body and dispersed in different places on the beach.

A beach seine fishing crew is the collective in action of different camaradas [companions or comrades] and apparatuses. The comrades include the vigias [lookouts], the remeiros [rowers], the patrão [owner] of the net, the chumbaleiro (who casts the net in the sea), the cozinheiro [cook], the livreteiro [treasurer], the homem do cabo (who swims with the point of the net from the canoe to the beach), the companions on the beach, who combine with the other neighbors, friends and relatives who help drag in the net to the sand. The apparatuses include the nets that are hundreds of braças [fathoms] long, ${ }^{6}$ canoes, paddles, buoys, radios, lookout stands, fishing shacks, cellphones, as well as other equipment and structures that reappear on the coastal landscape during the season.

The operative sequence that moves the fishing crew, the relationship between instruments and gestures (Leroi-Gourhan, 1987: 52), can be summarized as those between the gestures of the lookout (observing the sea, identifying schools of mullet, estimating their size and direction) and the canoe (entering the sea and overcoming the surf, paddling and surrounding the school, releasing the net, returning to land, closing the circle) with the net (circling the school in the ocean, pulling the two points of the net to land while keeping it extended, concentrating the fish in the central part of the net, removing the fish from the net, storing the net) and in the rancho [shack] (dividing the quinhões [shares] of fish, selling or trading fish, cooking and preparing for a new launch). As we saw, when the crew is in action, it displays many combinations and variations of this sequence that reveals subtleties of the perceptual skills involved in artisanal fishing.

6 The nets of the Saragaço crew, at Barra da Lagoa, have 400 braças [fathoms] (880 meters) and another with 600 braças (1,720 meters). 


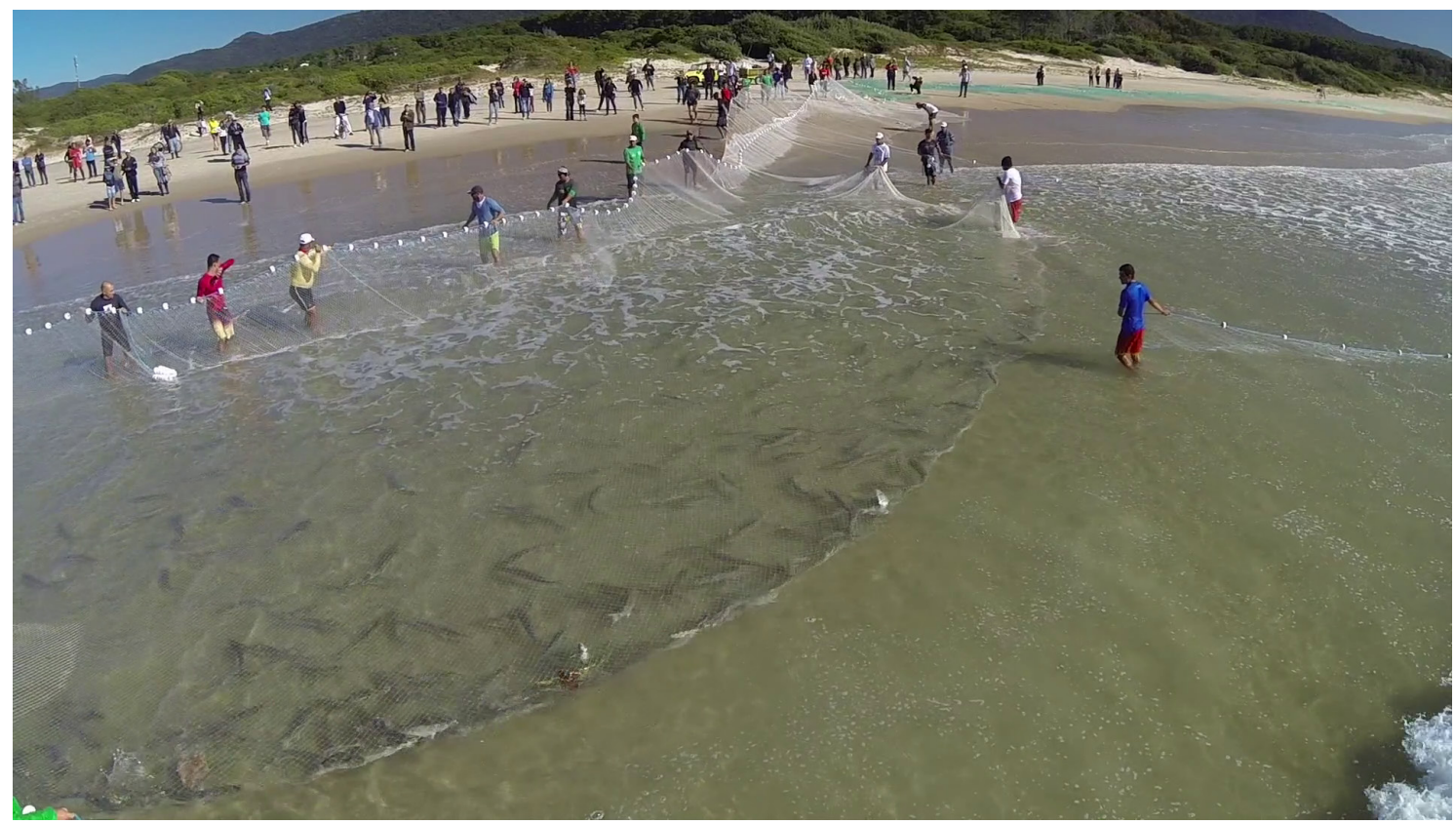

Image 3: Image of a sequence in video of a launch, available at the site of the project http://verpeixe.tumblr.com/post/148378332988/canoa-saragaço-lanço-no-dia-12062016-magote-de Last access on 20/06/2018.

It is this operational sequence and the environmental conditions that it requires that distinguish fishing with a beach seine from other modalities of mullet fishing in the season, which are also considered artisanal fishing by the fishermen because they are practiced in similar forms of social organization, by the same networks of kinship and neighbors (partnerships, comraderies) and with similar knowledge of the behavior of fish and the sea, but which are not always understood as such by the public policies.7 We refer to fishing in small boats that are distinguished from industrial fishing because they do not use mechanized winches or professional crews, but that, depending on the technical adaptations employed, ${ }^{8}$ can increase by many tons the capacity for capturing fish. Due to indications of decreasing fish stocks, the number of licenses for mullet fishing issued by public agencies to so-called artisanal fishing by boat has declined in recent years due to the calculation that the method has had a considerable impact on mullet fishing in general. The same took place with industrial fishing. While the artisanal fishing with beach seine nets conquered a differentiated place among the public policies, at least in the city of Florianópolis. One of the main reasons is its consonance with other public policies linked to the right to public access to the shore in opposition to the privatization of coastal areas caused by the construction of large developments. Another reason is that artisanal fishing requires the maintenance of local environmental conditions to be able to attract the schools to the beach. This engages these fishermen in the defense of forms of regulation of the fishing activity and of rights to access to the beach that, as we affirm here, is a political dimension of the category artisanal fishing, because of the connection that it establishes between the sea, the fish and the local communities that are found on the beach.

\footnotetext{
7 The commercial artisanal fishing "is that practiced by a professional fisherman, in an autonomous manner, or in a regime of family economy, with its own means of production or through a partnership contract, from land or with the use of boats with Gross Tonnage (GT)1 smaller or equal to 20 ". Meanwhile, industrial commercial fishing "is that practiced by a physical or legal person, with the involvement of professional fishermen employed or in a partnership regime, using small, medium or large boats (of any GT), for a commercial purpose (art. 8o, inciso I, "b", da Lei no 11.959, known as the Fishing Law)." (Brasil, 2017).

8 Fishermen who use small boats in Santa Catarina are known throughout Brazil for their inventions and for adapting technical systems from large trawlers (such as components of the mechanical winches for the nets), the use of sonar and modifications to the hull of the boats to improve movement and increase their capacity for capture. This is an issue for another discussion, which we do not have space to conduct here.
} 
While the use of sonar, GPS devices, more powerful motors and mechanical adaptations in the drag net can improve the capacity and speed of capture of the motorized boats, the adoption of new equipment in beach seine fishing does not change the decisive character that the behavior of the fish, the sea and winds has in this fishing modality. For the fishermen, the artisanal character of beach seine net fishing is not contradictory to the use of equipment such as binoculars, radio communications, cell phones, internet, cameras or to the materials used in the net or canoe, because their use depends on the development of the corporal abilities and techniques needed to perceive and "kill fish". Therefore, to understand this political character of this artisanal fishing it is necessary to understand this relationship between the techniques and abilities with the perceived environment. One of these abilities is central to the effectiveness of fishing: that which is known as the vigia [lookout] or ver peixe [seeing fish].

\section{Seeing fish: perception and the biosemiotics of mullet}

The practice of the lookout is the foundation of this knowledge of the coastal environment. In artisanal fishing, with paddle canoes and drag nets from the beach, the lookout is the beginning of the entire fishing endeavor in the season. Along the coastline, observation posts are re-erected in places suitable for watching the sea for the eventual presence of fish, taking advantage of the local relief and locations in relation to the sea and to the presence of marine currents. Destined to shelter lookouts from sunrise to sunset, throughout the season, these posts are composed of benches, platforms and even small huts located either along the beach in the sand or in sand dunes, on rocks or on hillsides. In addition to observation from these special locations, the lookouts can walk along the beach on foot, or use a bicycle or motorcycle to follow the passage of schools along the beach.

Positioned a few meters from the sea, the lookouts are the fishing comrades who spot fleeting manifestations of the fast fish, who show themselves very briefly in the ocean. Through this perceptual ability, the good lookouts know how to evaluate the approximate number of fish in the school, distinguishing between magotes (literally a crowd, used to refer to dozens or hundreds of fish) or mantas (literally a blanket, used to refer to thousands of fish), to differentiate the species of the school (between what are probably mullets, ${ }^{9}$ bluefish, ${ }^{10}$ bonitos ${ }^{11}$ or short-fingered anchovy ${ }^{12}$ ) and estimate their speed and direction. In their interactions on the beach with the speed and intensity of the wind, the transparency of the seawater, the strength and direction of waves, the luminosity of the day, the lookouts unveil the environment and perceive its variations, rhythms and movements that indicate the presence of mullet and the means to circle them.

In addition to giving the signal for the launch (the act of surrounding the school with the net), the lookouts have an important role in the synchronization of the movements of the canoes and nets with the movements of water and schools, and it is up to them to guide the other fishermen in the canoe and on the beach about how to cast the net: the moment to go out, the direction and speed to take with the canoe, the opening of the curve to be made and the return to the beach, the line taken by the net in the water and the positioning of the copo, which is the central part of the net and the last part removed from the water and which has most of the fish that were circled. The ability to see fish can be a significant difference between killing a few dozen or thousands of mullet in a single launch with the net. The operational sequence of fishing on the beach begins, therefore, with the practice of the lookout, and depends on it.

\footnotetext{
Mugil brasiliensis, Mugil liza, or Mugil platanus

10 Anchovas (Pomatomus saltatrix) begin to appear in the middle of the mullet season and with greater abundance at the end of the mullet season. They also have commercial value, but often break the net used for circling mullet.

11 Sarda sarda. Have little commercial value because of the small size in which they appear on the beach.

12 Manjuvas, or manjubas (Anchoa lyolepis). They are very small, used mostly for bait.
} 
In the company of the lookouts, from whom we learned the subtleties of environmental perception involved in this practice, we were challenged to look in another manner: to "look around" (Gibson, 1986: 203) and sweep the panoramic coast of the sea with the eyes and ears, to feel on our skin the changes in climate and locate ourselves in relation to everything that moves and is reshaped on the coastal landscape, which we have analyzed in detail in other works, problematizing our choice for the use of panoramic photographs (Devos, Vedana e Barbosa, 2016).

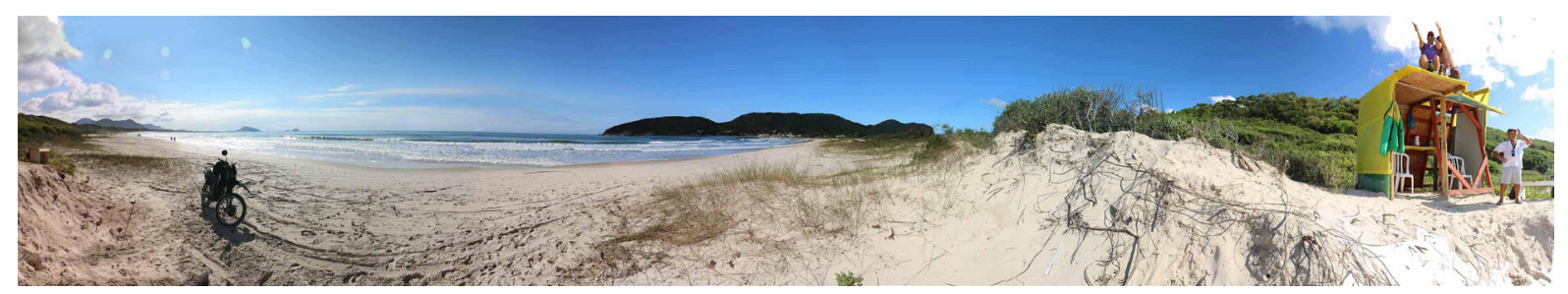

Image 4: panoramic photo of the lookout, available on the site of the project http://verpeixe.tumblr.com/image/128593790398. Last accessed on 20/06/2018.

It is not by chance that binoculars or other optical instruments for expanding the vision are not used by the lookouts to see the schools. It is not a question of observing a specific point far out at sea, but of perceiving the coastal landscape according to what Ingold (2011: 131-132) defined as "wheater-world", an environment in constant formation by the inscription of atmospheric and material forces and actions of many beings that are found on the beach. It is subtle changes in certain patterns of movement and transformation of the landscape that can indicate the passage of schools.

Perceptual skill is how James Gibson (1966: 51), who proposes an ecological approach to perception, formulates the inseparable character of perception and action. To perceive the environment is not limited to receiving (internalizing) stimuli by passive and specialized sensory organs and then constructing a mental image. Perception requires the development of modes of attention in the operation of one or more perceptual systems, through the adjustment of gestures, postures and exploratory movements and signs of ecological events that require an environmental arrangement. In the case of the lookouts, the visual system is associated to the haptic and auditory systems, dedicated to these signs distributed in the landscape. To perceive is to move in relation to an environment that is revealed between permanences and changes in the arrangement in its elements (Gibson, 1986: 170).

Edward Reed (1988: 122), upon approximating Gibson's ecological psychology to the biosemiotics of the ethologist Uexküll, proposes understanding the environment precisely as that which can be shared through perception. ${ }^{13}$ Meanings are not only mental elaborations of an observer, but signs of presence expressed in the movements of beings and agents in the landscape, changes of state in the textures, surfaces and dispositions of various elements. Reed approximates James Gibson's (1986:130) concept of "affordance", which is that which the environment propitiates to the organism, meanings recognized directly in perceptive actions, to Uexküll's (1992: 320) concept of Umwelt, which refers to the perceptual worlds of each animal species according to its perceptive capacity. The affordance breaks the apparent isolation of beings in their respective "own worlds", allowing that mutual perceptions-actions be shared as ecological events, opening the perception of meanings to multispecies relations. This is one interesting proposal for understanding the lookouts' descriptions about the ways of perceiving the appearance of the mullets that the lookouts say "show themwselves" in a relational form to the lookout post and the environmental conditions. The most common descriptions are:

13 A similar reflection is presented by Carlos Sautchuk (2007; 2012), both from the perspective of investigation, relating technique, perception and biosemiotics, and by a reflection on the importance of the production of images based on technical gestures in the hunting for Pirarucu in Vila Sucuriju, Amapá. 
- correndo na onda [running in the wave]: just before the moment a wave breaks, mullets can be seen passing through a more transparent part of the wave, which also depends on the direction of the rays of sunlight, the luminosity of the day and the clarity of the water;

- no vermelhão or no amarelão [in the deep red, or the deep yellow]: when they are concentrated, the mullet can form dark blotches (vermelhão), that indicate thousands of mullet (mantas) or smaller more dispersed blotches (amarelão), that indicate hundreds of fish (magotes);

- na aguada, ressolho or arrepio when they stir the surface of the ocean to form a different pattern of interaction between waves and wind;

- no pulo [jumping]: when one or more mullet are seen jumping out of the water, which is important for knowing the direction of the school;

- na barrigada: when they produce silvery reflections on the surface of the water as they move.

The direction of the tide, the texture of the surface and the color of the water are related to the direction and speed of the wind, and indicate the direction of movement of the mullet. To know the depth and constant formation of sandbanks on the sea bottom, to know if there are deep spots, rises or seaweed is also part of this revelation of the schools of mullet, given that these other elements also form blotches and textures that can confuse someone who does not know the place. There are times of day when the mullet can show themselves more, when they group in the morning, mid-day and late afternoon, or even no reponto da maré, which is the transition of the outgoing and incoming tides.

Although the lookout is known as the authority for assuring correct information about the presence and behavior of schools on the beach, his knowledge is shaped in relation to the manifestations of many agents that can be considered in a technical system. In it, even the shared images and news of fish combine with information about the environment. Other animals, such as dolphins ${ }^{14}$ that chase the schools of mullet, confirm their presence and form, which may be espalhados (dispersed). Meanwhile, birds such as terns ${ }^{15}$ or gulls ${ }^{16}$ which dive to capture small fish, indicate the presence of schools of other species, such as bluefish, which feed on small manjuvas. Boats that cast their nets far from the beach indicate, in addition to the presence of a school, the probable direction that the fish that escape the net will take, depending on the wind and the currents. The same is true for the fish that are seen or circled on other beaches, because those that escape can head to the space of capture of another crew. More than seeing the fish, the lookouts estimate changes in the formation and movement of various schools along the coast.

The ecological knowledge about these patterns of relations depends more on revelation than representation (Bateson, 1972). Each new manifestation in the environment adds distinctions to these patterns of relations, which the lookout considers when deciding the right moment to announce the launch, given that the noise of the entrance of the canoe in the water, the bustle of the comrades on the beach and the placement of the net in relation to the depth of the beach indicate to the school how to escape. The mullet also watch the environment and the fishermen, that is, the patterns of movement of the schools are rearranged according to how the same environmental agents (wind, tides, marine animals etc.) act in the landscape, even the fishermen, boats, surfers, and noisy restaurants. Hearing by the mullet, which is conducted by the fishes' perceptual system, is emphasized by the fishermen as the means by which the fish perceive presences in their path. It is the reason for which the mullet is considered the most intelligent among the species captured by the fishermen.

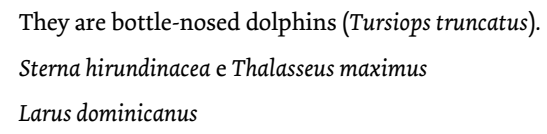


The schools that approach the beach are disputed by the crews that circle the schools at the edge of the beach and by small motorized boats, authorized to capture from a distance of 150 meters from the shore. On the beaches in which there is more than one crew operating, an agreement determines the preference for a certain crew to launch. These agreements may be established according to location (by allocating parts of the beach) or by day (by determining a preference according to days of the week), allowing the other crews to place their net in the sea after the first crew has made its circle. The school must enter the space of capture, to cast the net in the sea and be able to close it with the school inside, pulling the two points of the net on the beach. But the launch with a paddle canoe, and even more so one made with a motorized boat, can scare the school, because the mullet, which are smart, observe the fishermen, the boats and the beach. The fish shift their route as soon as they sense a presence. The news of fish, combined with the lookout practice, allows updating the monitoring of these movements of the schools.

\section{News of fish: ecology of instruments and distributed cognition}

This complex system of communication is similar to what Hutchins $(1995 ; 2001)$ calls "distributed cognition", given that the information about the presence and behavior of the schools, and about the conditions of the sea and the atmosphere are found distributed among and are propagated by members of a single and different crews and boats, by individuals of other animal species (dolphins and marine birds) and by various devices (fishing nets, canoes, cell phones, walkie-talkies, webcams, social network pages, and others). Even if one or more lookouts coordinates the propagation of information and makes the final decision about the launching of the canoe and the casting of the net, he or they never command all the activities, delegating tasks and operations to others, and to devices.

In general, upon seeing a possible sign of the presence of a school, the lookout communicates to one or more lookouts to share and confirm his perception. It is not rare that long debates begin about the presence or not of fish, their quantity and behavior, the conditions for and the best way to catch them. These conversations necessarily involve the owner of the canoe and eventually other comrades in the crew. In any case, the launching of the canoe in the sea, the casting of the net and circling the school will only be realized with the authorization of a reputable lookout and or the owner of the canoe. This division of tasks, not only among the lookouts, owners and other comrades, but also among lookouts with more or less prestige, is reflected in the difference in the size of the "quinhões", that is each one's share in the division of the fish captured in each launch. ${ }^{17}$

The information that arrive in face to face interactions, or by radio, telephone, and even through images that circulate on the social networks of mullet captured in other beaches are appreciated as new signs of possible revisions in patterns of relations, and have a part in the operational sequence that results in a new catch.

There is no opposition between new technologies and the techniques of artisanal fishing, in this case. The fishing is still artisanal, counting on the effectiveness of the practice that begins with the perception of the school by the lookout and that continues in the correspondence between the movements of the school and the movements of the collective body of fishermen, the canoe and the drag net on the beach. We present some brief accounts and images that show how this system of information is shared:

\footnotetext{
17 For an analysis of a similar aspect among the members of small herring fishing fleets, during the Norwegian winter, see Barth (1981: 40-47). The author analyzes the relative and complementary (transactional) behavior that is established between the captain, the owner of the net and the fishermen themselves. These behaviors are, according to the author, guided not only by contractually defined status and differentiated in authority, abilities and shares, as by technical and environmental limitations that establish a need for cooperation.
} 


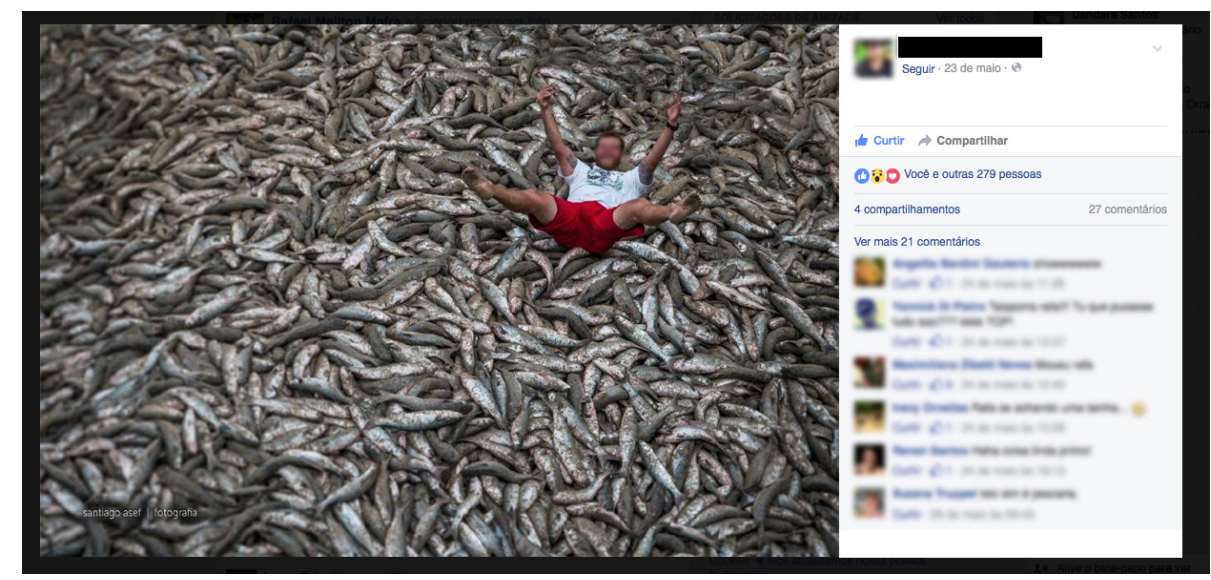

Image 5: photo of a launch that landed 37 thousand mullet, in Bombinhas, SC, shared during the 2016 season. Author: Santiago Asef. Source: http://www.facebook.com. Last accessed on 20/06/2016.

"At the lookout point on the Bay, amid the dunes, some neighborhood residents pass by, wanting to exchange Fish news. One lookout, Baía, says that he only saw a few fish jumping in the waves. His neighbor passes information from a cousin from the beach at Santinho, which is north of Barra da Lagoa: that morning they caught 2,00o mullet, from a manta of fish that indicated an even larger number. Baía thought that with the weak north wind, the fish that escaped the net at Santinho could come down to Barra da Lagoa. This is what he told the lookout Leandro by radio: to keep watch for the possibility of a run of a magote. Another neighbor was interested in the news. He ran to get his throw net at home, because fish could appear on the beach, which is good for fishing with the large net of a canoe, but also for a small throw net." ${ }^{\text {18 }}$

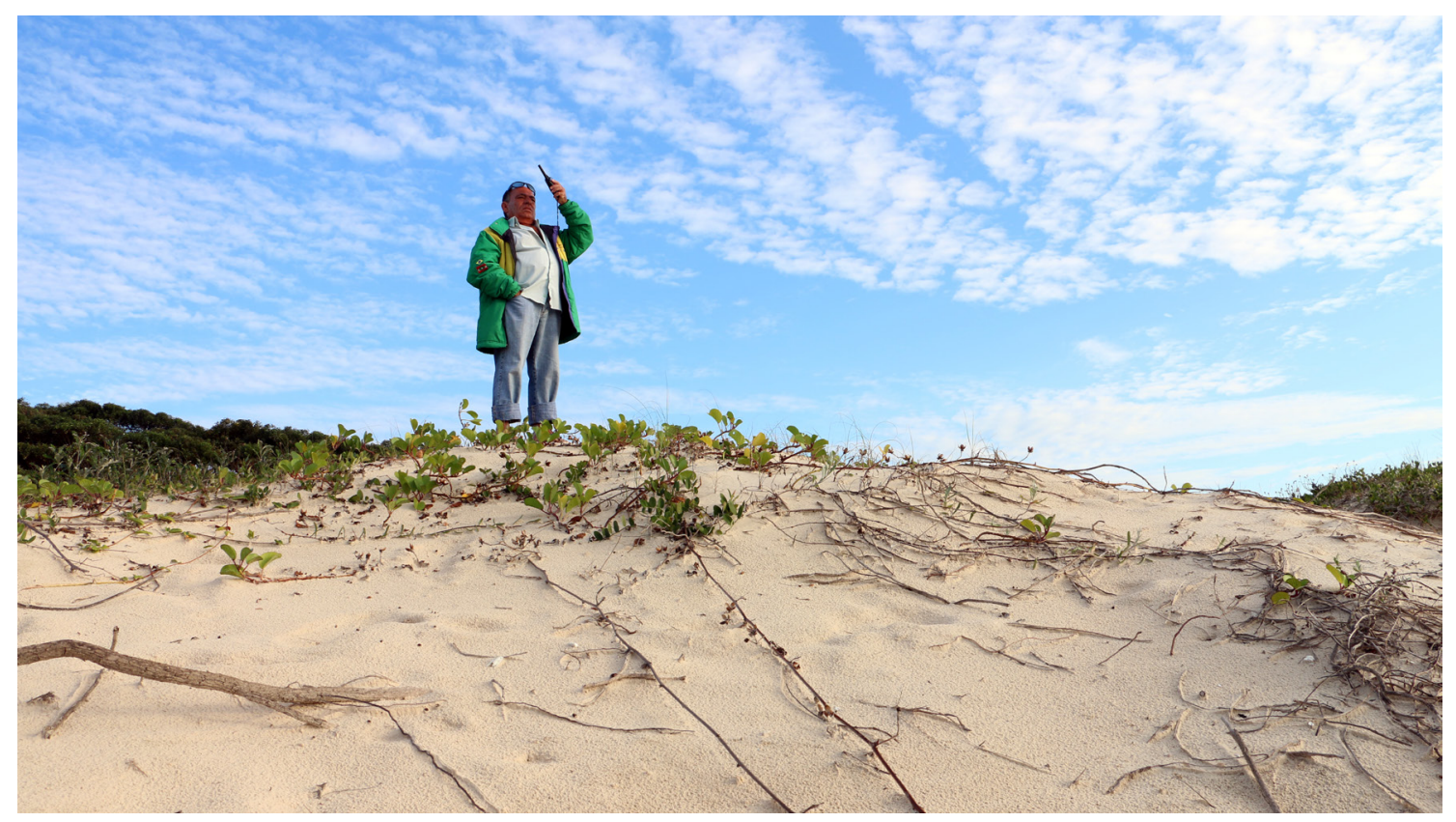

Image 6: Lookout Baía. Photo by Rafael Devos.

18 The tarrafa [a cast net or throw net] is a net for individual use that is thrown by spinning the body so that the net opens in a circular shape. It is cast when standing on rocks, in the water, or in the waves. When the tarrafa drops in the water, the fisherman pulls a cord that he closes quickly, capturing up to dozens of fish with this gesture, in a good cast. In addition to the technique of this circular gesture, using this net also depends on the practice of watching the movement of the school, and anticipating its movement. 
"While we head to the beach, we follow the tip of some fishermen who are also surfers. We consult by smartphone two webcams strategically positioned at the beach of Barra da Lagoa. Provided by websites linked to tourism and surfing, they show a live image of the movement in the early hours of the day, at two points of the beach. The images show what we accompanied at various moments of the field work: the atmospheric conditions of the first light of day, the arrival of the comrades in front of the fishing shack, the positioning of the canoe at the edge of the sea. We consulted the same site and others about the weather and especially the wind - its direction, speed and the time it was expected to change. The weak wind from the north indicated calm, little intensity, as the images of just a few fishermen on the beach indicated the absence of schools for the launch. If many fishermen were around the canoe, or were pointing to the sea, this is a sign of lots of fish. This was not the case on this day, but the image could indicate some movement of fish".

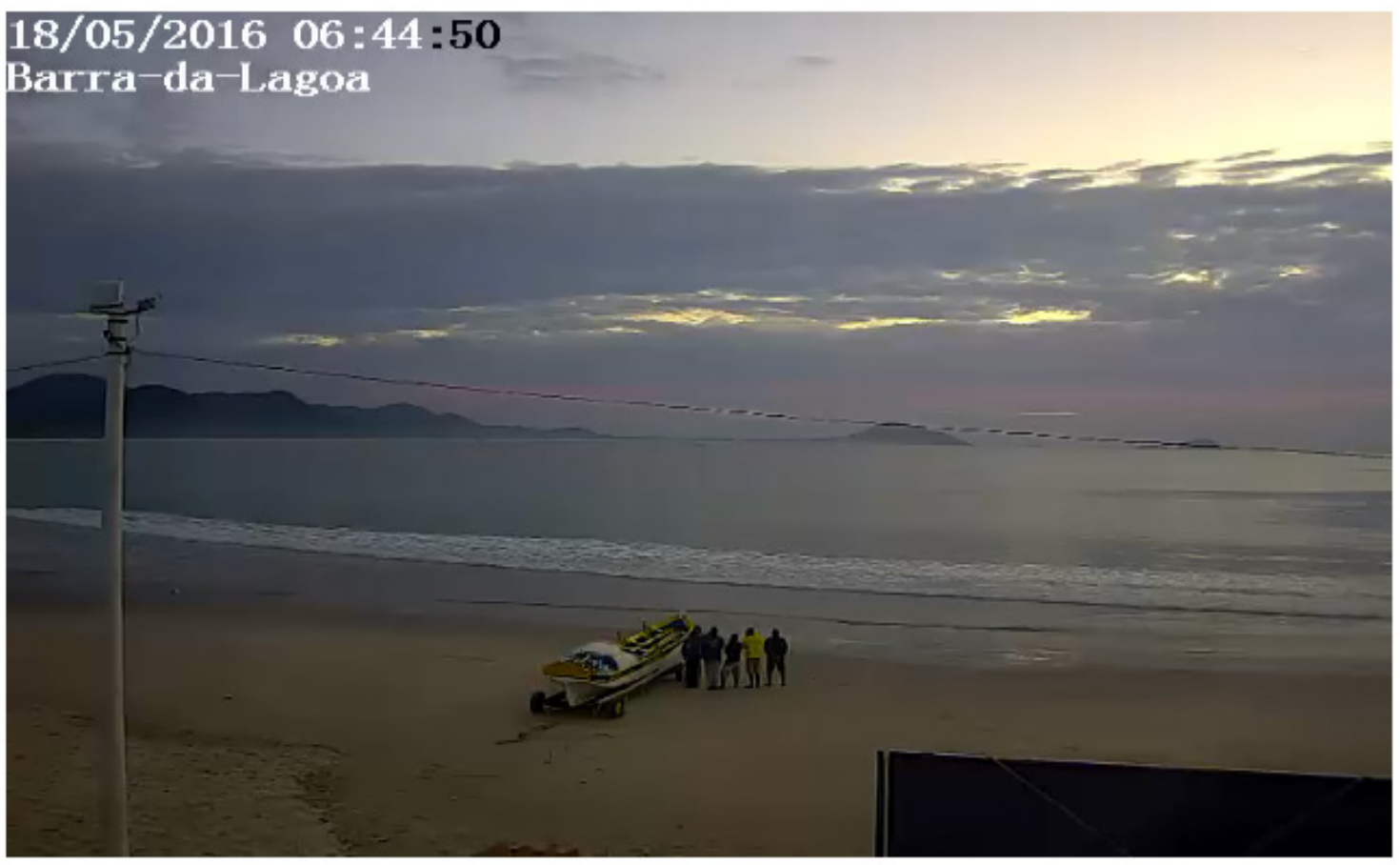

Image 7: photo from a webcam of the "Boletim das ondas" [Wave bulletin] website for surfers.

Source: http://inparadise.com.br/boletim-das-ondas/barra-da-lagoa-ao-vivo. Last accessed on 18/05/2016.

"Over the walkie-talkie, information arrived from the crew boss. That morning 2,00o mullet were caught at the beach of Santinho; 600 in Ingleses; and 1,800 at the beach of Lagoinha. All to the north of Barra da Lagoa, in Florianópolis. The sources of information are also mentioned: a lookout, a fisherman, the owner of the net. One boat is seen far off, leaving the canal that connects the Lagoa da Conceição [a lagoon] to the sea. By the color and size of the boat, the lookouts recognize the fishermen on board, and know they are experienced. They comment on the direction that the boat took: north. But other boats on the horizon go to the south, placing new suspicions about where there may be fish. The lookout Marquinhos shows photos on his phone that he received from his fishing group on Whatsapp, from the largest launch until then in that year, it was a few days ago at the beach of Farol [lighthouse] de Santa Marta, in Laguna, to the south of Florianópolis: 40 tons of fish! They lament the absence of a south wind, which could bring the schools seen in Laguna, 10okm away, to the coast at Florianópolis." 

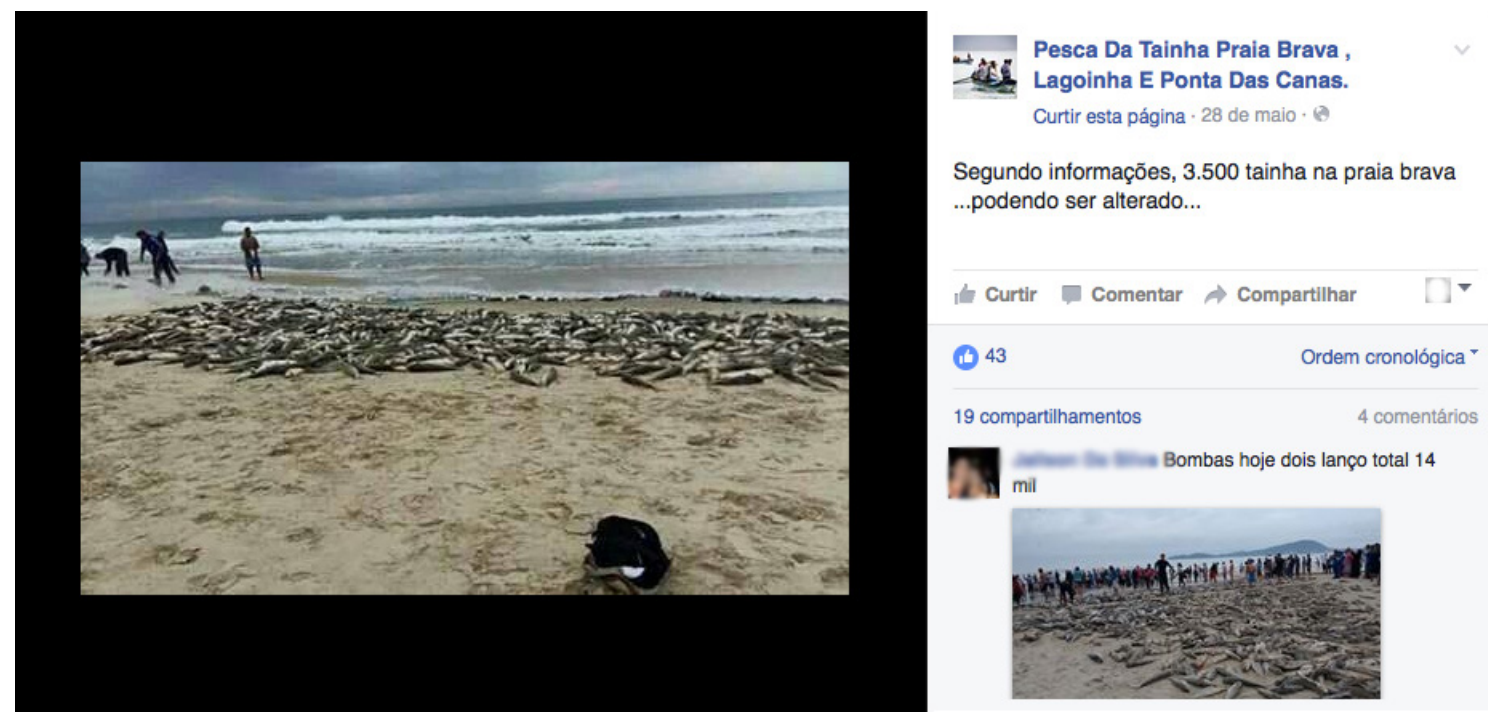

Image 8: post from the crews from the north of Santa Catarina Island, during the 2016 season.

"According to some information, there are 3500 mullet at Brava Beach... the numbers can change...".

Source: http://www.facebook.com. Last accessed on 20/06/2016.

"With giant binoculars, Miguel observes a boat in the distance, heading north - "they are laying the net, they saw fish there!" The binoculars are used to watch the boats and the fishermen, not the fish. Meanwhile, in the fishing shack, the amateur radio that is turned on captures messages from boats that have gone to sea. The mullet began to show themselves in small quantities along the beach. In front of the fishing shack, the fishermen gather slowly and discretely around the canoe. We approach, with our equipment in place, hoping to record the launching of the boat and the casting of the net on video. Chinho shows on his phone the whatsapp fishing groups that he participates in, all are rigorously restricted to fishermen: Turma da tainha SC, [The Mullet Group $\mathrm{SC}$ ] a group of fishermen of all the modalities such as canoes, small and large motorized canoes, amateurs; Bota a canoa [Launch the canoe], an exclusive group of owners of non-motorized canoes and lookouts of artisanal fishing on the beaches in the city of Florianópolis and the surrounding regions. Another fisherman, Eiro, shows the group in which he participates: Informações de pesca [Fishing information], a group organized by some beach lookouts, fishermen on boats and friends. But even the group Boletim das ondas [Wave Bulletin] becomes a source of news about the sea's conditions for fishing, more than for surfing, which is prohibited on many beaches on the island during the mullet season. The members of the groups exchange jokes, memes, teasing among friends, but mainly daily information about the weather conditions, the sea, and the success with the fishing of each crew, circulating news about fish in Santa Catarina, Paraná, Rio Grande do Sul, both of fishermen on the beach, and those on boats." 


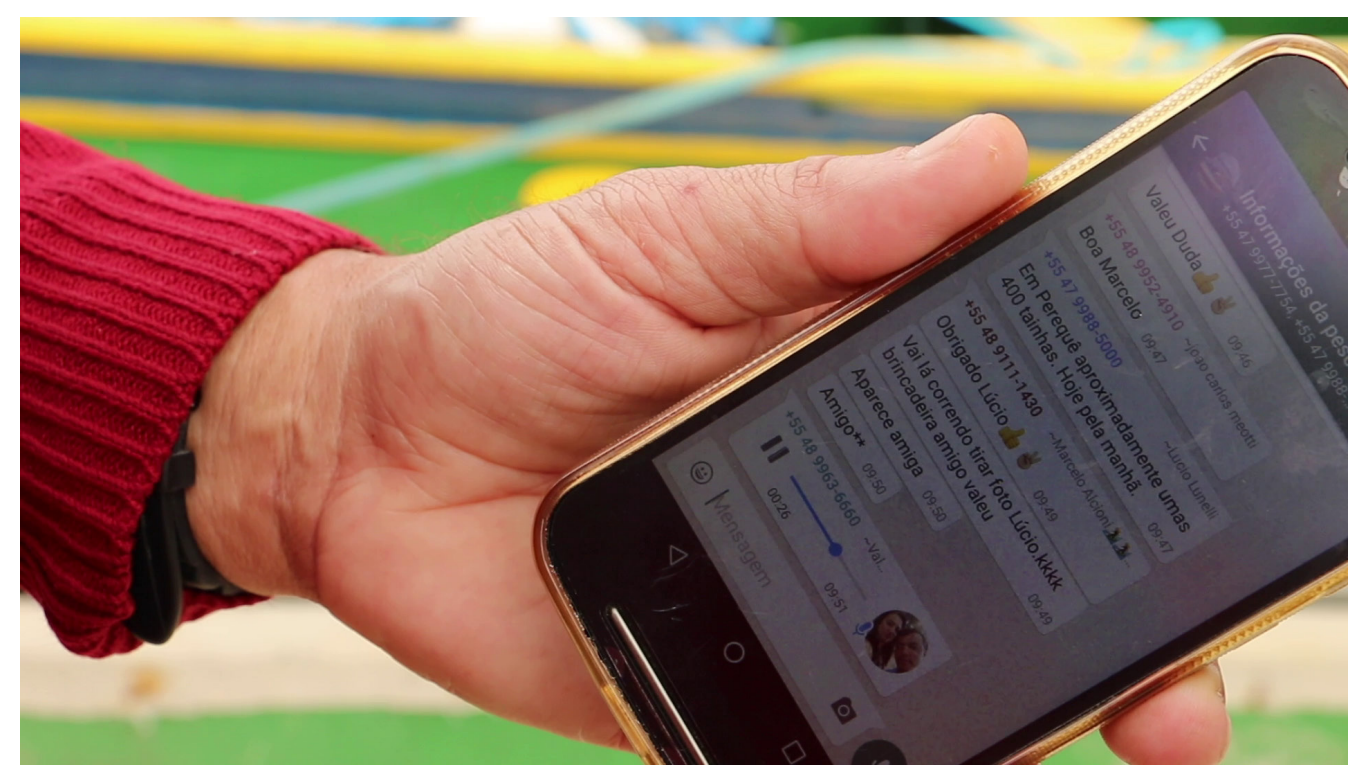

Image 9: frame of a sequence from the documentary film Ver Peixe (2017).

"At Perequê, there were approximately 400 mullet, this morning."

The movement of the mullet crossing the coast from Argentina, Uruguay, Rio Grande do Sul, Santa Catarina and Paraná is constantly evaluated by the fishermen during the lookout. Generally, the fish news is shared during or after the capture, not before. If there are fish in the sea, as indicated by the lookouts, the fishermen disguise the tension until the right moment. They avoid pointing to the sea or becoming agitated. As in the way they lookout for fish, they lookout for other fishermen and are observed by other fishermen, by the movement in the sea at a distance, by the internet, on the phone, by radio. The confirmation of the quantity comes later, in the separation of the shares of fish that each fisherman earns, or in the weight in tons when it passes thousands of fish.

The lookout for schools is the beginning of the fishing effort, but to See Fish is what all the fishing comrades practice, because although the mullet show themselves, they only reveal themselves in fleeting moments, to those who know how to see them. When the schools of fish perceive the fishermen, who reveal themselves by affecting the waves with the canoe or through movement on the beach, the schools change their course, they try to escape. To see the mullet from inside the canoe while rowing also guides the boss in the operation of the remo de governo, which serves as the rudder, in the acceleration of the remos de voga which paddle the canoe, or in the way that the chumbeleiro casts the net in the water, using it as a counterweight to synchronize the movement of the canoe with the waves and be able to surround the school with the canoe and the net. At the edge of the beach, during the dragging of the net, the fish show themselves trying to escape at loose points in the net, which is a sign that the fishermen should secure the lead weights on the bottom of the net with their feet or expand the opening of the net, to avoid their escape. The schools run from one point to another of the net in search of a gap for escape, which requires a synchronized dragging of the two points of the net until the school is gathered in the copo, the central part of the net in which the fish are concentrated and can be pulled to the sand. Only at this moment is when all the comrades in the crew and the other people who join the effort of the dragging confirm the estimate of the lookouts. The school comes to be seen, now covered with sand, and is divided into shares in the amounts to which each one who participated in the launching has a right, finally confirming the success of the fishing on that beach, with special value given to exchanges among the neighbors, relatives and clients. The launch also culminates with an evaluation of the number of wise fish that escaped the net, the canoe and the ability of the lookout, the boss or the comrades to effectively circle the school, which was always discussed again while they watched our images. 
At this time, we discovered that we also became a source of Fish News, like any other person who participates in the sociality of fishing, as we perceive the more frequent presence of video cameras and photography among the fishing collectives themselves. The images that we made in our study, like the images made by the fishermen themselves, were made through an engagement in this same operational sequence of fishing. They are submitted to the same temporality between the moments of waiting and watching and the vigor of the moment of the launching, adopting the same forms as the fishermen reaching the school, through the circling with the net. They accompany a flow of images that are exchanged, in the challenge of being able to photograph or record the highest number of fish on the beach, and their effects on the communities where the mullet circulate. The images feed the cycle of these practices, informing new possibilities for the next launch, by the geographic position of the beach where the capture was made and the direction of the winds and ocean currents.

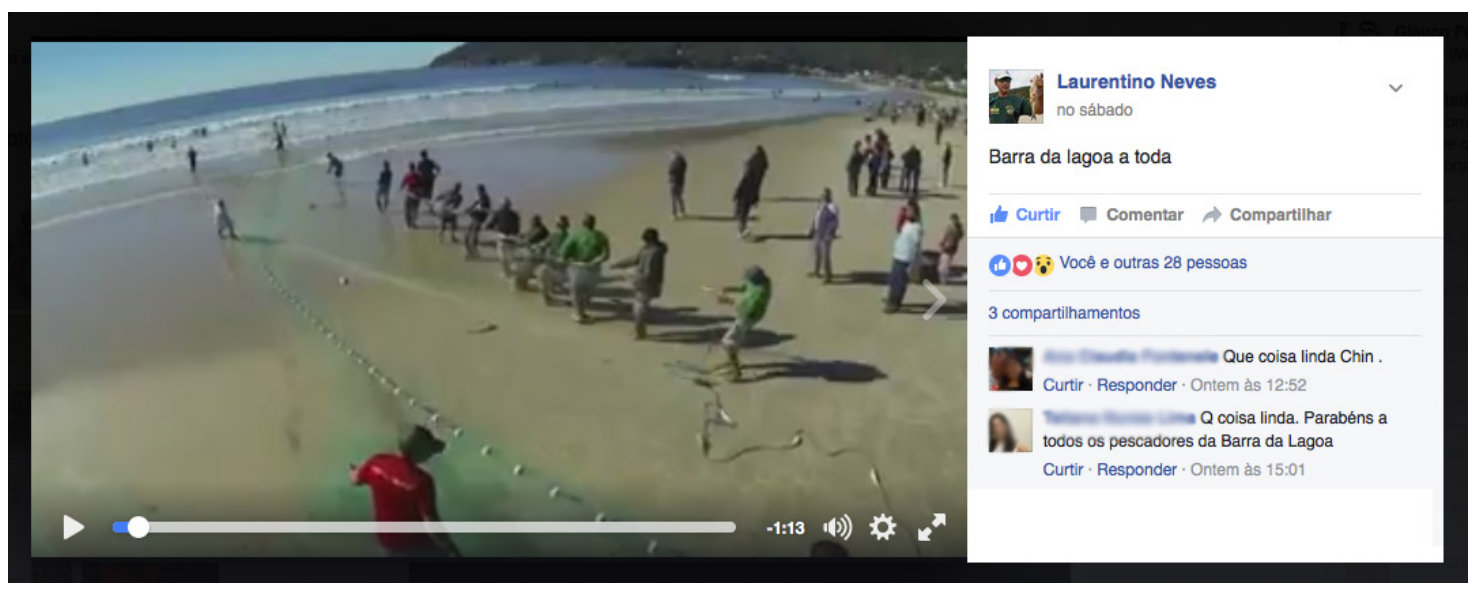

Image 10: video produced by the study, shared with the fishermen of Barra da Lagoa in the 2016 season. Source: http://www.facebook.com. Last accessed on 20/06/2016.

It is in this sense that we understand the insertion of smartphones, cameras and radio communication systems in the practices of artisanal fishing as a continuity and not a rupture with traditional and efficient artisanal techniques. The traditional component of the practice is manifest in its realization and transmission in a collective manner, amid the sociality and exchanges between the fishermen in their networks of work, kinship and neighborhood. This modality particularly stands out as artisanal and effective in the way that it maintains certain ecological relations between the collectives of fishermen and the environment of the beach and the fish. If the modalities of industrial fishing are more efficient in capturing tons of fish far from shore, artisanal fishing is more effective in bringing the schools to the beach as well as residents of the city. The reciprocity with those who participate in the launch aggregates value and a different flavor to the extremely fresh fish that circulates in a different way in the exchanges among neighbors and clients. The quality of the fish from the beach is the result of this process of individuation that transforms the fish into food for the community involved, taking with it information about its origin, which confirms its difference from frozen industrial fish. ${ }^{19}$

19 The fish from the beaches of Santa Catarina is more highly regarded locally because it is understood that in their travel to the north from the lagoons, like the Lagoa dos Patos or Laguna, the fish modify their feeding, from the substrate at the bottom of the lagoons, which gives them an "earthy taste", to the substrate at the bottom of the ocean, which changes their flavor. In addition to the substrate material in the mullets' food, the knowledge revealed by the artisanal fishing with a beach seine allows understanding another distinctive quality of the fish caught from the beach, expressed in this substrate that is aggregated to relations that are materialized in the fish from Barra da Lagoa, Campeche, Lagoinha and other coastal villages, which are sought during the mullet season. It is a fact that is different from that presented by recent monitoring policies, which has occurred since 2017, aimed at the establishment of a system of fishing quotas to limit the mullet catch on the Santa Catarina coast. This system does not distinguish the fish caught by artisanal fishing from that of industrial fishing, and within the artisanal category, or the fish from the beach and that caught in boats. Although this monitoring includes participation of fishing collectives in the data collection, it does not recognize their contributions to knowledge about the life of the mullet between the sea and land. About this monitoring, see the site tainhômetro: http://tainhometro.com.br/ (last accessed on 20/11/2018). 


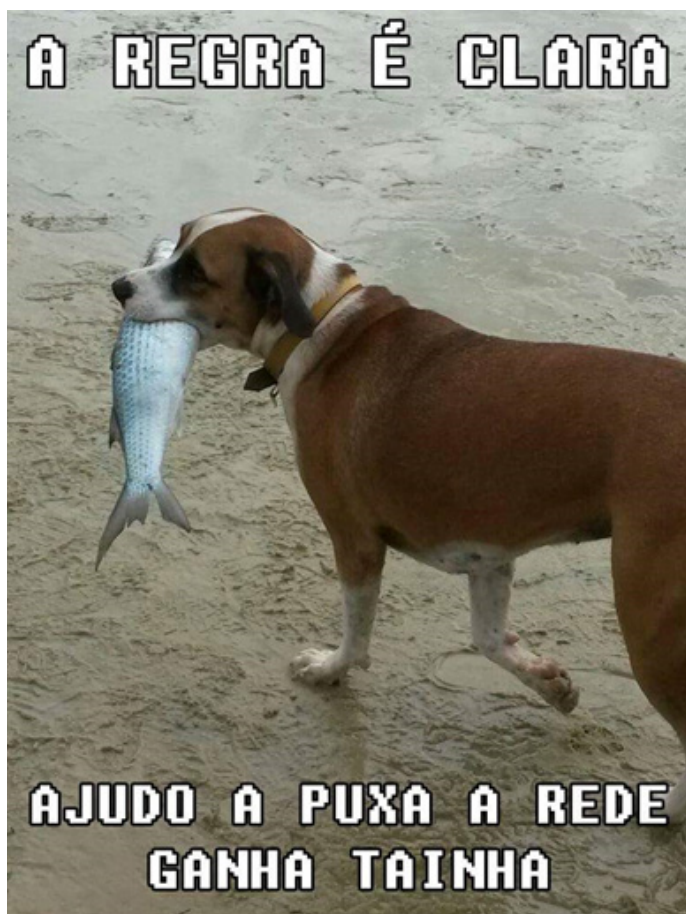

Image 11: photo shared during the 2016 season.

[It reads, "The rule is clear, those who help pull the net, get a mullet"]. Source: Whatsapp. 17/05/2016.

\section{Following the effects of the school}

To record these operational sequences in images and sound also involved perceiving another component of these skills: the rhythmic adaptation of the gestures of the collective of the crew to the changes in movement of the schools, the sea and the winds, in relation to the beach. That is, the launches are never the same, and vary according to countless environmental factors. Therefore, there is no ideal operational sequence to register, or a single traditional form of casting the beach seine to be transmitted from generation to generation. After all, the artisanal character of this fishing resides precisely in the fishermens' ability to re-encounter, through a process of "guided rediscovery" (Ingold, 2000: 353-356; 2011: 162), these variable combinations of elements that guide their own changes in state on the beach, from rest and contemplation during the lookout until the intense moment of the launching.

The variations in the operational sequences correspond to the rhythmic adjustments in the technical gestures, as Leroi-Gourhan (1987: 86) observed, in relation to the forces with which they relate. Tim Ingold (2011: 60) observes that these modulations in technical flows are the condition of the artisanal practice of corresponding to the materials, through the artifacts, the way that the material acts on the artisan and vice-versa.

These rhythmic adjustments can also be considered in the industrial fishing by boat, because it also includes fishermen remaking gestures and regulations in the operation of the boats and winches for the nets in relation to the schools and the sea. But there is an important difference, to the degree that the technicity is developed in a different way in each case in relation to the environment. Based on the studies of technique by Gilbert Simondon (2008), we affirm that the quality of this relationship would be a large difference between beach fishing and industrial fishing. The mechanized boats, which use winches and sonar, operate to reduce the unpredictability of the environment, with nets with small mesh that are dragged on the bottom of the ocean for long periods, transforming into catch any body that touches the net, with an internal coherence and autonomy in the concretization of a technical object (Simondon 2008: 77) invested in the maximization of its objectives. 
Artisanal fishing, meanwhile, with the beach seine, because it is realized with nets with larger mesh and is based on the abilities to perceive the environment, is a system more open to environmental variations. But for this reason, it is more effective in the selection of fish to circle and in the capture of the schools of large mullet. The mullet caught by artisanal fishing with beach seine nets in fact become the fish of the location, because the process does not involve nature becoming an economic resource, but fish that individuate themselves as mullets on the Santa Catarina coast, at Barra da Lagoa or Campeche, which become unique and have a different flavor, aggregating parts of relations.

The same logic can be considered in the production of the documentary. It did not involve investing in sophisticated equipment like telephoto lenses or underwater equipment to produce images of fish. To the contrary, it involved finding equipment that could withstand the environmental conditions of the recording, like the constant contact with sand, wind and water. We opted to use small action-cameras for the images along the ocean and in the canoe, a portable audio recorder and a DSLR camera ${ }^{20}$ for the moments of lookout and the final dragging of the net. The operation of the equipment was shared among the researchers. Moreover, when operating the cameras and microphones we chose to adjust our technical gestures to the collective gestures undertaken by the crew and the agents with whom it related. We turn here to the concept of operational sequence (chaîne opératoire), to guide our discussion.

The description of the operational sequence, sequentially following (but not necessarily linearly) these processes that mutually affect each other and that involve rhythmic adjustments between humans and nonhumans, is a special form of perceiving this complexity of relations, as Coupaye (2015: 73-74) commented well, as a sole manifestation of possibilities of relations in a technical process, in which certain conditions of relationship are necessary. For example, there is not a single type of wind associated to the presence of the mullet, as a more classificatory approach would determine. It is necessary to have a south wind of a certain intensity for a few days to bring the schools from the south, but it must be interrupted by a north, east or northeast wind, depending on the position of each beach, for the fish to come to the beach and with luck a subsequent calm would facilitate the sea conditions to navigate the canoe. Even so, the schools can pass the beach to other areas on the coast, or come close at a place where it is difficult to operate the net or canoe, because of rocky bottoms or an irregular coastline. Moreover, at any moment, the passage of a dolphin or a boat can scatter and alter the course of the school.

Our initial proposal was to visit various beaches and record the work of crews during the mullet fishing season in the city of Florianópolis. Although accompanying the work of the lookouts in various places on different days was relatively easy, it was not at all easy to coincide our presence with the time of the launch or the presence of the fish on a specific beach. A number of times we were with lookouts at a beach who received news by radio or a cell phone that a crew at another beach, where we had been a few days earlier, had just caught hundreds of thousands of fish.

In addition to being unique, each launch, as the complete system of capturing the fish is known, becomes part of the beginning of a new launch, because it allows the crew that executed it and the crews on other beaches to reevaluate the movement of the schools, the direction they were seen heading, on which part of the beach, and in combination with what atmospheric and oceanic conditions were they seen and surrounded. The previous launch, as well as the action of the fishing boats that also exchange information with the lookouts, can scatter the schools, and direct them to the space of capture of another crew. Thus, the images that we recorded also become part of this system of fish news, and were incorporated like other narratives, to the operational sequence, a relationship that is recurring in studies of chaînes operatoires. ${ }^{21}$

20 Camera: Gopro Hero 3 Black; Camera: Canon DSLR EOS 7oD, 18-135mm lens; and audio recorder Zoom H6.

21 If "operational sequence" (chaîne operatoire) is initially a concept that defines human actions in the construction of an object, aggregating tools and corporal techniques, it progressively comes to be better understood as a methodological tool, encompassing information that indirectly influence the operational sequences, beyond the narrow description of techniques, as factors that influence the ethnographic work itself (Lemmonier, 1992: 26) 
To understand the expansion of the lookout practice from the beach, as a system of monitoring of schools of fish on the Santa Catarina coast, implies understanding that it involves knowledge that is less about the species of mullets and their nature, and more about the relations of the fish with each one of the beaches known by the fishermen according to their specificities: the way that they face the north, east or south and are thus exposed to winds and currents from different directions, and have either a large stretch of sand or are formatted into small bays, or are perhaps surrounded by dunes or rocky coasts close to the entrance of lagoons or rivers. Each curve and each rock has a name related to fishing and fishermen: "Pedra do Vigia" [Lookout Rock], "Ponta do Marisco" [Mussel Point], "Vigia do Paço" [Paço's Lookout], "Pedra da Baleia” [Whale Stone], "Vigia da Cruz" [Cross Lookout], "Ponta do Siliveira" [Siliveira's Point], and many others. In this case, the coastal landscape named in the toponyms acts as an important artifact in the ecology of the fishing instruments and practices, so that this system of information is shared in the way it is described.

In contact with other fishermen positioned at these lookout points or in boats traveling along the southern coast of Brazil, the perception is expanded of large mantas of mullets seen on the coast of Rio Grande do Sul, which escaped boats in Rio Grande, and had come from the cold waters of Uruguay, or that even reached the municipalities in the north of Santa Catarina. The lookout is expanded to far beyond the local beach, observing the movement of the mullet in the ocean for many kilometers, awaiting their passage in front of one's lookout point, hoping that the schools escape other nets.

According to Lemonnier's (2013) reflection about narrative and technique, it is possible to understand that conversations during the lookout about the news of fish, the evaluations by the fishermen, the exchanges of images and narratives of the previous days, are the fishing occurring once again. They are part of a new operational sequence of artisanal fishing in action, less perceptible than the sequence of gestures on the beach and the dragging of the net. It is these daily conversations, expanded on the social networks through smartphone applications that allow the lookout to confer other meanings to what takes place to the south or north of the beach where he is found. The news is also important in the evaluation of the "harvest", which is how they refer to the number of total fish from all the modalities in the fishing along the coast, considering the studies about the decrease in fish stock at the Lagoa dos Patos and polemics related to the lack of control of industrial fishing. These issues also lead the artisanal fishing collectives to take a particular political action during the preparation for each fishing season.

\section{Ecological Mise-en-scène}

How is it possible to film the school that just passed by? How is it possible to capture with the camera the mullet that the lookout just pointed out? This was an initial concern of the study, which led us to try to learn and develop the ability to see fish, as a principle of the mise-en-scène of the documentary - that is, the way it places actions, presences, expressions in scene to express their meaning through the treatment of the image.

When we presented the first research images to the fishermen, in the form of panoramic photographs, a recurring comment was the absence of fish in the images and the fishermens' desire that we be able to register in video a large quantity of mullet on the beach. It was soon clear that it was not an image of the fishermen's practice of seeing fish that would show their effectiveness, but its effects on the operational sequences of fishing and its recursiveness in the confirmation of the ecological information that is shared in each gesture. Thus, the engagement in this practice allowed us to transform our practices of production of images, by experimenting with other modes of seeing and showing the fish, together with the fishermen and their technical objects (such as the net and the canoe). 
The knowledge involved in the ability to see fish has a precise relationship to the environment. It is not an imaginary representation, an allegory in relation to fish, but a bit of news, an image, or narrative that provides information about the presence of schools in relation to a system of references on the landscape. It is not so much what is a fish, but what it does, its form of existence is important in the sense that is essential to understand what the fish are doing and how to reach them. Thus, the meaning of the images that we were producing was anchored in this indicial sequence that linked one sign to another on the landscape and that initiated the various movements in response. It was not necessary to ask the fishermen about the meanings, but to follow them, discovering these signs in their reactions to what we showed them. To learn to see fish, it is necessary to understand this practice as a revelation to the attention of the fishermen, and not as a transmission of knowledge, as Ingold (2011: 162) presents to us, based on the ideas of Bateson (1972) and Gibson (1986). This revelation stems from a sensitive ecology in which the world shows itself to the engagement of the lookout with what is moving in the landscape.

The recording of images follows the effects of environmental transformations that show the fish in the gestures, postures and expressions of the lookouts. Given that it was improbable to anticipate where the fish would appear, we followed the reactions of the fishermen as indications of the biosemiotics of the mullet, taking advantage of the progressive approximation of the crew with the fish as a way to also approximate the camera to the mullet, which were easier to frame when found in larger quantity. By shifting the camera from the position of the lookout to the canoe, or to the net in the water, the environmental indications in the landscape had their effects on the lenses and the microphone. Other abilities could be narrated if we focused on the corporal engagement with the paddles and the canoe for example. But the lookout is certainly the ability most possible to be shared among all the fishermen. Even if some are more skilled and recognized for their precision, to see fish, it is necessary to initiate all those involved with the crew, like the sons of the fishermen, or even the researchers.

The knowledge needed for artisanal fishing does not reside in the head or in the body of one individual, as Hutchins (2001) commented about distributed cognition. The different ways of participating in the practice of fishing (either in the lookout, paddling the canoe, pulling the net on the beach etc.) imply different ways of developing correspondences (Ingold, 2013: 107) with the movement of the school and the sea, through the net, the canoe, at the edge of the beach, or even of the news exchanged daily.

Different from Coupaye (2015) and other studies that describe operational sequences as transects or visual schemes, we opted to use audiovisual narratives to describe these re-encounters of the fishermen with the schools on the beach, which approximated us to the ways they systematized this knowledge, in fish news. To also see and sense the fish, through images, it was necessary to do as the fishermen do, observe the various movements on the landscape, whether at sea, or on the beach, of the fishing comrades. The challenge of capturing with the camera the encounter of the fishermen with the schools, approximates the audiovisual image with a corporeal image, as suggested by David MacDougall (2006: 7). In this case, it involves the body of the lookout, as well as the body of the net being stretched by the tide and by hands and legs, and the body of the heavy canoe and its crew hitting the wave, or of the fish fleeing in the water.

To be able to record the fish, it was necessary to adopt various camera angles and approximations involved in the physical relationship in which some of these elements can be recognized, that is, in order to perceive their affordances (Gibson, 1986). We accompanied the corporeal relations of the lookouts as they horizontally scanned the coastline, highlighting horizontal movements that indicate directions of movement. We encountered the continuation of these gestures in the actions of both the canoe approaching from an opposing direction (and for this reason we placed the camera on the bow), and of the net being pulled perpendicularly, alternating between the surfaces of land and water. Following the movement of the net, it was also possible to approximate the camera to the fish in the sea, whether observing their attempts to escape by jumping through the waves at 
one of the points of the net, or, with the camera in the water, awaiting the contact of the fish with the netting. Meanwhile, the capture of sound followed the principle of leaving the microphone to be struck by bodies in contact - the sand carried by the strong wind, the water splashed by the flailing mullet, the tension of the stretched net between the opposing forces of the sea and the comrades in the dragging, the slap of the body of the fish hitting against each other. We also used a drone at some special moments, to allow embracing in a single framing the encounter of the entire crew in action with the fish, during the dragging, showing the two arms of the net being dragged, as well as the fish being enclosed within it.

The montage of the audiovisual is not the moment in which a discourse about the fishing is elaborated, after fieldwork. It constitutes another technical gesture in which this rhythmic interweaving can be continued, transposed to another sequential form, which is not linear, but rhythmic, subject to the movements, interruptions and detours that can entangle the spectator among fundamental gestures: waiting, acceleration, traction and distension. The duration of the images for the montage is given by the rhythm of the oars hitting the sea, waves, the racing mullet and fishermen, transposed to the verbal blows issued by the lookouts and the owner of the net, as they coordinate the movements of the canoe, the arms and legs as they drag the net, keeping it open and taut in the sea, until culminating with the agitation of the fish as they take their last breathes in the sand. After all, we did not capture the fish with the camera, we were captured by the rhythmic engagement of the fish, the beach, the lookout and the launch, which, during the mullet season, record their marks on the coastal landscape of Southern Brazil.

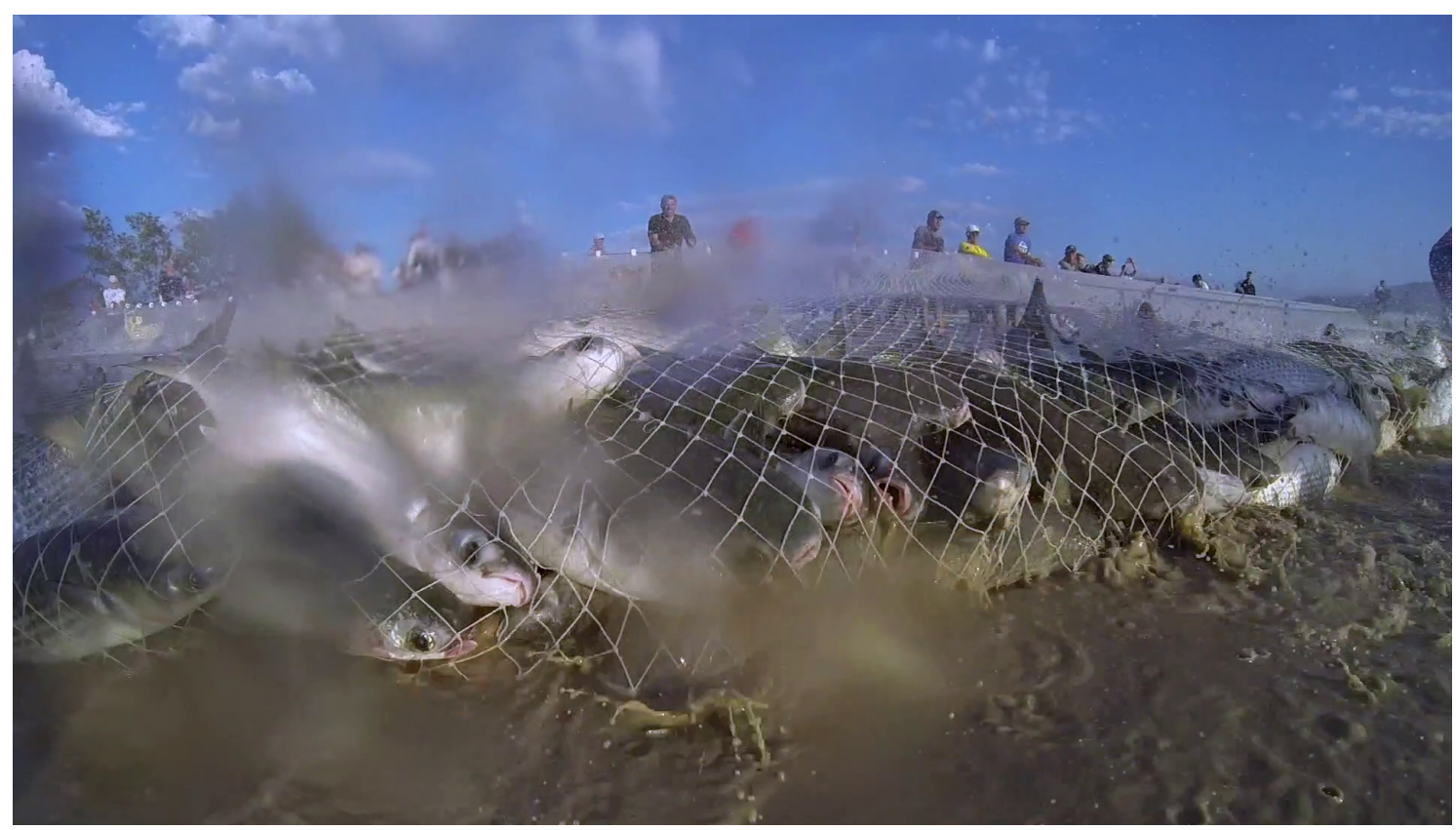

Image 12: image from the trailer of the film Ver Peixe (2017) found on the research site http://verpeixe.tumblr.com/post/169733068948/verpeixe-seeing-fish-2017-46-min. Last accessed on 10/07/2018. 


\section{References}

BARTH, Fredrik. 1981. "Models of Social Organizations I". In: Process and Form in Social Life. Selected essays of Fredrik Barth, Volume I. London, Boston and Henlley: Routledge \& Kegall Paul. pp. 32-47.

BATESON, Gregory. 1972. Steps to an Ecology of Mind. Collected Essays in Anthropology, Psychiatry, Evolution, and Epistemology. São Franciso: Chandler.

BRASIL. Ministério Público Federal. 2017. Pesca artesanal legal : pescador da região Sul/Sudeste : conheça seus direitos e deveres. 6a Câmara de Coordenação e Revisão, Populações Indígenas e Comunidades Tradicionais. Brasília : MPF.

COUPAYE, Ludovic. 2015. "Chaîne opératoire, transects et théories: quelques réflexions et suggestions sur le parcours d'une méthode classique". In: P. Soulier (ed.), André Leroi-Gourhan, "l'homme tout simplement". Paris: Éditions de Boccard/Travaux de la MAE. pp. 69-84.

DEVOS, R.; VEDANA, V; BARBOSA, G.. 2016. "Landscapes as panoramas and audiovisual rhythms: environmental perception in mullet fishing." Revista GIS - Gesto Imagem e Som, 1(1): 41-58.

DIEGUES, A. C. 1983. Pescadores, Camponeses e Trabalhadores do Mar. São Paulo, Ática.

GIBSON, James. 1966. The Senses Considered as Perceptual Systems. Boston: Houghton Mifflin Company. . 1986. The ecological approach to visual perception. Nova York: Psychology Press.

GONÇALVES, J. R. 1996. A retórica da perda: os discursos do patrimônio cultural no Brasil. Rio de Janeiro: Editora UFRJ/IPHAN.

HUTCHINS, Edwin. 1995. Cognition in the Wild. Cambridge (USA): MIT Press. . 2001. “Cognition, distributed”. In: N. Smelser; P. Baltes (eds.), International encyclopedia of the social \& behavioral science. Amsterdam; New York: Elsevier. pp. 2068-2072.

INGOLD, Tim. 2000. The Perception of the Environment: essays on livelihood, dwelling and skill. Londres: Routledge. . 2011. Being Alive. Essays on movement, knowledge and description. New York/London: Routledge. 2013. Making. Anthropology, archaeology, art and architecture. New York/London: Routledge.

LEMONNIER, Pierre. 1992. Elements for an anthropology of technology. Michigan: Museum of Anthropology.

Anthropological Papers, n. 88. . 2013. "Míticas cadeias operatórias." Amazônica Revista de Antropologia, 5(1): 176-195

LEROI-GOURHAN, André. 1987. O Gesto e a palavra 2 - memória e ritmos. Lisboa: Edições 70.

KANT DE LIMA, R.; PEREIRA, Luciana. 1997. Pescadores de Itaipu: meio ambiente, conflito e ritual no Estado do Rio de Janeiro. Niterói: EdUff.

MACDOUGALL, David. 2006. The corporeal image: film, ethnography, and the senses. Nova Jersey: Princeton University Press.

MAUSS, Marcel. 2003. “As técnicas do corpo.” In: Sociologia e Antropologia. São Paulo: Cosac \& Naify. pp. 399422.

MUSSOLINI, G. 1945. "O Cerco da Tainha na Ilha de São Sebastião". Revista de Sociologia, 7(3): 135-147.

REED, Edward. 1988. "The affordances of the animate environment: social science from the ecological point of view". In: T. Ingold (org.), What is an Animal? London: Routledge. pp. 110-126.

SAUTCHUK, Carlos E. 2007. O Arpão e o Anzol. Tese de Doutorado. Brasília, UNB. . 2012. "Cine-weapon: The poiesis of filming and fishing". Vibrant - Virtual Brazilian Anthropology, 9(2). Brasília: ABA.

SIMONDON, Gilbert. 2008. Du mode d'existence des objets techniques. Paris: Aubier-Montaigne.

UEXKÜLL J. von 1992. "A stroll through the worlds of animals and men: A picture book of invisible worlds". Semiotica, 89(4): 319-391. 


\section{Audiovisual}

VER PEIXE. Documentário. 46 min. 2017. Florianópolis, Brasil. Realização: DEVOS, R.; VEDANA, V.; BARBOSA, G. C.

Rafael Victorino Devos

https://orcid.org/0000-0001-5985-0155

Address for correspondence:

Servidão Manoel Isidoro Augusto, 279. Florianópolis, SC. 88048-446.

E-mail: rafaeldevos@yahoo.com

Gabriel Coutinho Barbosa

https://orcid.org/o0oo-0003-0347-9638

E-mail: ggabrielbar@gmail.com

Viviane Vedana

https://orcid.org/oooo-0002-1132-5973

E-mail:vi_vedana@yahoo.com 